\title{
Motor cortex stimulation for neuropathic pain
}

\author{
Helen Smith, R.G.N., Carlolf Joint, R.G.N., David Schlugman, F.R.C.A., \\ Dipankar Nandi, M.Ch., John F. Stein, F.R.C.P., AND Tipu Z. AzIZ, F.R.C.S. \\ Departments of Neurosurgery and Neuroanaesthesia, Radcliffe Infirmary; and University Laboratory \\ of Physiology, Oxford University, Oxford, United Kingdom
}

\begin{abstract}
Motor cortex stimulation is increasingly reported in the literature as a surgical option for the alleviation of neuropathic pain. The authors review the published literature and present their results including those demonstrated in a randomized controlled trial that confirmed the efficacy of the procedure. Patient selection and prediction of outcomes, however, remain difficult issues.
\end{abstract}

\section{KEY WORDS • motor cortex stimulation • neuropathic pain}

Neuropathic pain is one of the most difficult conditions to treat in clinical neurological practice. Drug therapy is inconsistently effective, even with the new generation of $\gamma$-aminobutyric acid agonists. Hence, the search for a surgical technique to alleviate this condition continues. Although many anatomical targets and surgical techniques have been used - often with the enthusiasm for any one depending largely on the opinions of the principal exponents-few have been subjected to controlled trials. In recent years, MCS has been explored by various groups in the pursuit of ways to alleviate neuropathic pain, and the results have been variable. This paper is intended to review the published results and techniques and to present an assessment of our own MCS-related results based on an objective, double-blind study.

Electrical stimulation with bipolar current, targeted in or near the internal capsule, and its positive effect on centrally mediated pain, was documented more than 20 years ago. ${ }^{4}$ Interest in MCS has since evolved in the search for an effective treatment in management of central poststroke-related pain, although it has since been shown to be useful for other peripheral neuropathic pain conditions, including trigeminal neuralgia and facial pain. The first reports by Tsubokawa and colleagues ${ }^{23}$ on the effectiveness of MCS on neuropathic pain were based on 10-year experience attained in the treatment of 25 patients in whom intermittent cortical stimulation was used. Their overall response rate was $75 \%$, with long-term benefits for up to 7 months in a patient group that had been resistant to all available pain therapies. Tsubokawa and associates ${ }^{22}$

Abbreviations used in this paper: $\mathrm{MCS}=$ motor cortex stimulation; VAS = visual analog scale. later published their findings based on a series of 11 patients with thalamic pain, in whom MCS was performed. A mean reduction in pain of $73 \%$ based on a VAS was demonstrated during initial trial stimulation in eight of these patients, in whom permanent internal systems were subsequently implanted. During the initial trial three patients experienced no response to stimulation. In the eight patients in whom MCS evoked a response pain relief was generally reported within 5 minutes of commencement of stimulation, and these positive effects faded within 10 minutes. Relief of pain was achieved using a range of 3 to $8 \mathrm{~V}$ at a level that did not result in muscle spasm. In five of these eight patients the same level of pain relief continued for a follow-up period of 2 years, receiving intermittent stimulation five to seven times a day. In three patients, however, the relief gradually subsided over a 1-year period. Subsequently, there has been growing corroborative evidence derived from case reports and series to suggest that stereotactic epidural MCS is an effective treatment for some patients with intractable neuropathic pain. Variable response rates related to various implantation techniques have been reported in patients with central and peripheral neuropathic pain. ${ }^{1-3,5-24}$ Table 1 provides a summary of these reported cases and series, as well as details of the optimum stimulator settings and the overall long-term response to MCS. The evidence suggests that a positive response is achieved in 44 to $100 \%$ of MCS-treated patients. Long-term benefits have been achieved in 0 to $100 \%$ of those patients who responded to initial trials of stimulation. There is some evidence that response to stimulation decreases over time in some patients. The response rates vary from 0 to $100 \%$, with series in which the population is larger than five patients, averaging a 50\% response. Adverse effects following MCS have been documented in 
H. Smith, et al.

TABLE 1

Summary of published data on the effects of MCS*

\begin{tabular}{|c|c|c|c|c|c|c|c|}
\hline \multirow{2}{*}{$\begin{array}{l}\text { Authors } \\
\& \mathrm{Yr}\end{array}$} & \multirow{2}{*}{$\begin{array}{l}\text { No. of } \\
\text { Cases }\end{array}$} & \multirow[b]{2}{*}{ Diagnosis } & \multicolumn{2}{|c|}{ Response } & \multirow{2}{*}{$\begin{array}{l}\text { Optimum } \\
\text { Settings }\end{array}$} & \multirow{2}{*}{$\begin{array}{l}\text { Adverse } \\
\text { Effects }\end{array}$} & \multirow[b]{2}{*}{ Comments } \\
\hline & & & Short Term & Long Term & & & \\
\hline $\begin{array}{l}\text { Tsubokawa, } \\
\text { et al., } 1990\end{array}$ & 25 & $\begin{array}{l}\text { deafferentation pain } \\
\text { (thalamic \& MCS) }\end{array}$ & NA & $\begin{array}{l}75 \% \text { response rate } \\
\text { at } 7 \mathrm{mos}\end{array}$ & NA & NA & NA \\
\hline $\begin{array}{l}\text { Katayama, } \\
\text { et al., } 1991\end{array}$ & 8 & $\begin{array}{l}\text { persistent vegative state } \\
\text { (possible DBS as } \\
\text { opposed to MCS) }\end{array}$ & $\begin{array}{l}\text { cerebral evoked po- } \\
\text { tential-painful } \\
\text { stimuli (p250) \& } \\
\text { motor response to } \\
\text { painful stimuli }\end{array}$ & $\begin{array}{l}\text { DBS increased p } 250 \\
\text { in } 4 \text { patients up to } \\
4 \text { mos }\end{array}$ & & & \\
\hline $\begin{array}{l}\text { Hosobuchi, } \\
\text { et al., } 1993\end{array}$ & 6 & $\begin{array}{l}\text { central deafferentation pain } \\
\text { (burning dysesthesia con- } \\
\text { tralat side of body), } 5 \mathrm{w} / \\
\text { poststroke, } 1 \mathrm{w} / \text { postresec- } \\
\text { tion of lt parietal AVM }\end{array}$ & $6 \mathrm{w} /$ complete relief & $\begin{array}{l}2-3 \text { mo FU: } 4 \mathrm{w} / \mathrm{ex}- \\
\text { cellent relief, } 1 \mathrm{w} / \\
30 \%, 1 \mathrm{w} / 0 \% ; 9-30 \\
\text { mos: } 3 \mathrm{w} / \text { excellent } \\
\text { relief }\end{array}$ & $\begin{array}{l}\text { Itrel II: } 3-5 \mathrm{~V}, \mathrm{PW} \\
\text { 180-160 msec, fre- } \\
\text { quency } 20-30 \mathrm{~Hz}, \\
\text { cycling mode, } 1 \mathrm{hr} \\
\text { on, } 6 \mathrm{hrs} \text { off }\end{array}$ & NS & $\begin{array}{l}\text { pain relief w/o } \\
\text { paresthesia or } \\
\text { motor response }\end{array}$ \\
\hline $\begin{array}{l}\text { Meyerson, et } \\
\text { al, } 1993\end{array}$ & 10 & central \& neuropathic pain & $\begin{array}{l}6 \mathrm{w} />50 \% \text { relief } \\
\text { during TS (for up } \\
\text { to } 4 \mathrm{wks} \text { ); no relief } \\
\text { in poststroke pain }\end{array}$ & $\begin{array}{l}\text { 4-28 mos FU } 6 \text { of } 6 \\
\text { w/ } 50 \% \text { relief }\end{array}$ & $\begin{array}{l}\text { subthreshold for } \\
\text { muscle spasm stim- } \\
\text { ulation (pulse du- } \\
\text { ration } 0.3 \mathrm{msec} \\
50 \mathrm{~Hz} \text { ); stimulation } \\
\text { during test period } \\
20-30 \text { mins } 3-5 \\
\text { times/day }\end{array}$ & $\begin{array}{l}\text { most had 1-2 } \\
\text { short-lasting } \\
\text { seizures dur- } \\
\text { ing TS; no } \\
\text { long term } \\
\text { motor effects; } \\
2 \text { w/ pain } \\
\text { over electrode } \\
\text { site; } 1 \text { of } 2 \\
\text { had epidural } \\
\text { clot requiring } \\
\text { surgery, result- } \\
\text { ing in expres- } \\
\text { sive aphasia } \\
\& \text { long-term } \\
\text { dysphasia; no } \\
\text { equipment fail- } \\
\text { ures; } 2 \text { of } 6 \text { had } \\
\text { electrodes re- } \\
\text { situated due to } \\
\text { local irritation }\end{array}$ & $\begin{array}{l}\text { no response in } \\
\text { poststroke pain; } \\
\text { placing of elec- } \\
\text { trodes crucial for } \\
\text { response } \\
\text { d }\end{array}$ \\
\hline $\begin{array}{l}\text { Tsubokawa, } \\
\text { et al., } 1993\end{array}$ & 11 & thalamic pain & NA & $\begin{array}{l}5 \text { of } 8 \text { had prolonged } \\
\text { relief at } 2 \text { yrs; in } 3 \\
\text { of } 8 \text { pain relief di- } \\
\text { minished }\end{array}$ & NA & none & NA \\
\hline $\begin{array}{l}\text { Katayama, } \\
\text { et al., } 1994\end{array}$ & 7 & $\begin{array}{l}4 \text { w/ bulbar pain (caused } \\
\text { by lat medullary infarct): } \\
3 \text { MCS, } 1 \text { MCS + TS }\end{array}$ & $\begin{array}{l}2 \text { of } 3 \text { w/ satisfac- } \\
\text { tory relief }\end{array}$ & NS & $\begin{array}{l}\text { subthreshold for } \\
\text { muscle spasm } \\
\text { (pulse duration } \\
0.1-0.5 \mathrm{msec} \text {; in- } \\
\text { tensity } 2-8 \mathrm{~V} \text { ) }\end{array}$ & NS & $\begin{array}{l}\text { MCS better than } \\
\text { TS for poststroke } \\
\text { pain }\end{array}$ \\
\hline $\begin{array}{l}\text { Canavero \& } \\
\text { Bonicalzi, } \\
1995\end{array}$ & 2 & $\begin{array}{l}\text { 1) male: cervical syringo- } \\
\text { myelia (pain lt arm } \\
\text { \& hemitorso), propofol } \\
\text { responsive; 2) female: } \\
\text { poststroke pain, pro- } \\
\text { pofol unresponsive }\end{array}$ & $\begin{array}{l}\text { 1) } 30-50 \% \text {; } \\
\text { 2) no relief }\end{array}$ & $\begin{array}{l}\text { 1) } 50 \% \text { pain spread } \\
\text { to contralateral } \\
\text { side at } 2 \text { years; } \\
\text { 2) N/A }\end{array}$ & $\begin{array}{l}\text { Itrel II } 5-7 \mathrm{~V} \text {, } \\
50 \mathrm{~Hz}, 300 \\
\mu \text { sec, } 0-3 \text { setting, } \\
\text { dosing } 30 \mathrm{~min} \\
\text { on, } 60 \text { min off, } \\
\text { cycling mode } \\
\text { (off at night) }\end{array}$ & NS & $\begin{array}{l}\text { 1) parietal cortex } \\
\text { stimulation; no } \\
\text { motor effects } \\
\text { intraop but par- } \\
\text { esthesia reported; } \\
\text { 2) no response }\end{array}$ \\
\hline $\begin{array}{l}\text { Herregodts, } \\
\text { et al., } 1995\end{array}$ & 7 & $\begin{array}{l}2 \mathrm{w} / \text { central poststroke } \\
\text { pain, } 5 \mathrm{w} / \mathrm{TGN}\end{array}$ & $\begin{array}{l}7 \mathrm{w} />50 \% \text { reduc- } \\
\text { tion in pain during } \\
\text { TS }\end{array}$ & $\begin{array}{l}\text { FU 9-22 mos w/ at } \\
\text { least } 50 \% \text { relief in } \\
5 \text { of } 7 ; 1 \text { of } 7 \text { (post- } \\
\text { stroke) w/ no relief } \\
\text { at } 4 \text { mos; } 1 \text { of } 7 \\
\text { (anesthesia dolo- } \\
\text { rosa) w/ only } 20 \% \\
\text { relief at } 6 \text { wks \& } \\
\text { no relief at } 13 \text { mos }\end{array}$ & $\begin{array}{l}\text { motor response } \\
\text { elicited during } \\
\text { TS }\end{array}$ & NS & $\begin{array}{l}\text { best response in } \\
\text { TGN; no de- } \\
\text { creased response } \\
\text { over time in those } \\
\text { w/ good initial } \\
\text { response }\end{array}$ \\
\hline
\end{tabular}

* amp = amplitude; AVM = arteriovenous malformation; DBS = deep brain stimulation; fMR = functional magnetic resonance; GABA = $\gamma$-aminobutyric acid; FU = follow-up; NA = not available; NS = not stated; PAG = periaqueductal gray area; $\mathrm{PW}=$ pulse width; RCT $=$ randomized controlled trial; TGN = trigeminal neuralgia; $\mathrm{TS}=$ test stimulation.

$\dagger$ Results reported in conference proceedings. 


\section{Motor cortex stimulation for neuropathic pain}

TABLE 1, continued

Summary of published data on the effects of MCS*

\begin{tabular}{|c|c|c|c|c|c|c|c|}
\hline \multirow{2}{*}{$\begin{array}{l}\text { Authors } \\
\& Y \mathrm{Yr}\end{array}$} & \multirow{2}{*}{$\begin{array}{l}\text { No. of } \\
\text { Cases }\end{array}$} & \multirow[b]{2}{*}{ Diagnosis } & \multicolumn{2}{|c|}{ Response } & \multirow{2}{*}{$\begin{array}{l}\text { Optimum } \\
\text { Settings }\end{array}$} & \multirow{2}{*}{$\begin{array}{l}\text { Adverse } \\
\text { Effects }\end{array}$} & \multirow[b]{2}{*}{ Comments } \\
\hline & & & Short Term & Long Term & & & \\
\hline $\begin{array}{l}\text { Peyron, et } \\
\text { al, } 1995\end{array}$ & 2 & poststroke pain & $\begin{array}{l}\text { both w/ good re- } \\
\text { sponse based on } \\
\text { VAS score }\end{array}$ & $\begin{array}{l}1 \mathrm{w} / \text { pain relief main- } \\
\text { tained at } 22 \text { mos; } \\
1 \mathrm{w} / \text { pain relief only } \\
\text { for } 3 \mathrm{wks}\end{array}$ & NA & $\begin{array}{l}1 \text { withdrew as } \\
\text { stimulation } \\
\text { produced un- } \\
\text { acceptable } \\
\text { burning pain } \\
\text { in lower lt } \\
\text { limb }\end{array}$ & \\
\hline $\begin{array}{l}\text { Ebel, et al., } \\
1996\end{array}$ & 7 & TGN & $\begin{array}{l}6 \text { of } 7 \mathrm{w} />50 \% \\
\text { reduction in VAS } \\
\text { pain intensity fol- } \\
\text { lowing TS }\end{array}$ & $\begin{array}{l}3 \text { of } 6 \mathrm{w} / \text { good to ex- } \\
\text { cellent pain control; } \\
\text { long-term FU 5-24 } \\
\text { mos; } 3 \text { of } 6 \text { positive } \\
\text { effects decreased } \\
\text { over several mos }\end{array}$ & $\begin{array}{l}\text { settings subthresh- } \\
\text { old for motor ef- } \\
\text { fects (Itrel II), amp } \\
3.5-10.5 \mathrm{~V} \text {, fre- } \\
\text { quency } 60-130 \mathrm{~Hz} \text {, } \\
\text { PW } 180-350 \mu \mathrm{sec} \text {, } \\
\text { cyling mode except } \\
\text { for } 1 \text { patient w/ con- } \\
\text { tinuous stimulation; } \\
20 \text { mins- } 2 \text { hrs on, } \\
3-10 \mathrm{hrs} \text { off }\end{array}$ & $\begin{array}{l}1 \text { of } 7 \text { w/ pro- } \\
\text { longed focal } \\
\text { seizure (post- } \\
\text { ictal speech } \\
\text { arrest) during } \\
\text { TS \& did not } \\
\text { undergo im- } \\
\text { plantation of } \\
\text { internal sys- } \\
\text { tem }\end{array}$ & $\begin{array}{l}\text { long term re- } \\
\text { sponse in } 3 \text { of } 6 \\
\text { who responded; } \\
\text { decreased re- } \\
\text { sponse over time } \\
\text { in some }\end{array}$ \\
\hline $\begin{array}{l}\text { Fujii, et al., } \\
1997\end{array}$ & 7 & thalamic pain & $\begin{array}{l}6 \text { of } 7 \text { fair to excel- } \\
\text { lent relief during } \\
\text { TS }\end{array}$ & $\begin{array}{l}6 \text { of } 6 \text { fair to excellent } \\
\text { relief at } 1 \mathrm{mo} ; 5 \text { of } 6 \\
\text { fair relief at } 3 \mathrm{mos}\end{array}$ & $\begin{array}{l}\text { no difference for } \\
\text { pain relief between } \\
10 \mathrm{~Hz} \& 100 \mathrm{~Hz}\end{array}$ & $\begin{array}{l}\text { fatigue in up- } \\
\text { per limbs at } \\
100 \mathrm{~Hz}\end{array}$ & $\begin{array}{l}\text { decreased response } \\
\text { over time in all }\end{array}$ \\
\hline $\begin{array}{l}\text { Garcia- } \\
\text { Larrea, et } \\
\text { al.,1997 }\end{array}$ & 9 & $\begin{array}{l}6 \mathrm{w} / \text { poststroke pain; } 3 \mathrm{w} / \\
\text { brachial plexus pain }\end{array}$ & $\begin{array}{l}3 \text { w/ }>80 \% \text { relief; } 2 \\
\text { w/ } 40-50 \% \text { relief } 4 \\
\text { w/ }<40 \%\end{array}$ & FU time NS & NS & NS & $\begin{array}{l}\text { in those w/ good } \\
\text { blood flow to an- } \\
\text { terior cingulate \& } \\
\text { PAG, good pain } \\
\text { relief was re- } \\
\text { ported }\end{array}$ \\
\hline $\begin{array}{l}\text { Nguyen, et } \\
\text { al., } 1997\end{array}$ & 20 & $\begin{array}{c}\text { deafferentation pain }(7 \mathrm{w} / \\
\text { TGN, } 10 \mathrm{w} / \text { central pain, } \\
1 \mathrm{w} / \text { peripheral neuralgia, } \\
2 \mathrm{w} / \text { spinal cord lesions })\end{array}$ & $\begin{array}{l}12 \mathrm{w} / \text { at least satis- } \\
\text { factory improve- } \\
\text { ment during TS; } 3 \\
\text { failed to respond }\end{array}$ & $\begin{array}{l}\text { 14-39-mo (mean } 25.1 \\
\text { mos) FU: } 14 \text { reported } \\
40-100 \% \text { reduction in } \\
\text { pain ( } 7 \text { of } 7 \text { w/ TGN, } \\
1 \text { of } 1 \mathrm{w} / \text { peripheral } \\
\text { nerve injury, } 80 \% \text { re- } \\
\text { lief); } 5 \text { of } 10 \mathrm{w} / \text { cen- } \\
\text { tral pain; } 1 \text { of } 2 \mathrm{w} / \\
\text { spinal cord lesion } \\
\text { excellent relief }\end{array}$ & $\begin{array}{l}\text { mean frequency } 40 \\
\mathrm{~Hz}(25-55 \mathrm{~Hz}) \\
\text { duration } 90 \mathrm{msec} \\
(60-180 \mathrm{msec}) \\
\text { amp } 2.4 \mathrm{~V}(1.3- \\
4 \mathrm{~V}) 3 \mathrm{hrs} \text { on, } \\
3 \mathrm{hrs} \text { off }\end{array}$ & $\begin{array}{l}\text { extradural he- } \\
\text { matoma in } 1 \text {, } \\
\text { resolved spon- } \\
\text { taneously; } 3 \\
\text { w/ dysethesia } \\
\text { at }>3 \mathrm{~mA} ; 1 \\
\text { w/ speech dis- } \\
\text { order } 6.6 \mathrm{~mA} \text {; } \\
\text { no technical } \\
\text { problems or } \\
\text { seizures }\end{array}$ & $\begin{array}{l}\text { pain relief main- } \\
\text { tained for } 24-48 \\
\text { hrs after TS; re- } \\
\text { lief decreased } \\
\text { over time in 5; } \\
\text { long-term FU: } 5 \\
\text { of } 20 \text { failed to } \\
\text { respond; } 15 \text { of } 20 \\
\text { at last FU, satis- } \\
\text { factory response }\end{array}$ \\
\hline $\begin{array}{r}\text { Rainov, et } \\
\text { al., } 1997\end{array}$ & 2 & chronic facial pain & $\begin{array}{l}\text { satisfactory relief } \\
\text { in both }\end{array}$ & $\begin{array}{l}\text { stable reduction in } \\
\text { pain in both at } \\
18 \mathrm{mos}\end{array}$ & NA & $\begin{array}{l}\text { epileptic seizure } \\
\text { in } 1 \text { patient } \\
\text { during FU }\end{array}$ & \\
\hline $\begin{array}{l}\text { Yamamoto, } \\
\text { et al., } 1997\end{array}$ & 28 & $\begin{array}{l}\text { poststroke, hemibody } \\
\text { pain }\end{array}$ & NA & $\begin{array}{l}\text { 12-mo plus FU: } 13 \\
\text { ( } 76 \%) \text { of } 28 \text { had } \\
\text { positive response } \\
\text { to MCS; } 10(71 \%) \\
\text { of } 14 \text { morphine-re- } \\
\text { sistant \& thiamylal- } \\
\text { or ketamine-sensitive } \\
\text { patients had positive } \\
\text { response to MCS }\end{array}$ & $\begin{array}{l}\text { continuous stim- } \\
\text { ulation for } 15-30 \\
\text { mins several times } \\
\text { a day; intensity } 2.5 \\
\text { V at } 25-50 \mathrm{~Hz}\end{array}$ & NA & $\begin{array}{l}\text { thiamylal \& keta- } \\
\text { mine sensitivity } \\
\& \text { morphine re- } \\
\text { sistance may be } \\
\text { predictor of re- } \\
\text { sponse to MCS }\end{array}$ \\
\hline $\begin{array}{l}\text { Canavero, et } \\
\text { al., } 1998^{\dagger}\end{array}$ & 9 & $\begin{array}{l}5 \mathrm{w} / \text { central pain, } 3 \mathrm{w} / \\
\text { neuropathic pain, } 11 \mathrm{w} / \\
\text { atypical facial pain }\end{array}$ & $\begin{array}{l}\text { central pain, } 3 \\
\text { of } 5 \text { responded, } \\
\text { neuropathic TGN, } \\
1 \text { of } 3 \text { responded; } \\
\text { facial pain, no } \\
\text { response }\end{array}$ & $\begin{array}{l}\text { central pain, } 1 \text { of } 3 \\
\text { continued to re- } \\
\text { spond at } 2 \text { mos; } 0 \\
\text { of } 1 \text { w/ TGN re- } \\
\text { sponded }\end{array}$ & NS & NS & $\begin{array}{l}\text { decreased re- } \\
\text { sponse over time } \\
\text { in some; trans- } \\
\text { cranial magnetic } \\
\text { stimulation, pro- } \\
\text { pofol, \& midazo- } \\
\text { lam were predic- } \\
\text { tors of positive } \\
\text { response to MCS; } \\
\text { possible mecha- } \\
\text { nism, GABA } \\
\text { mechanisms at } \\
\text { corticothalamic } \\
\text { level }\end{array}$ \\
\hline
\end{tabular}

* amp = amplitude; DBS = deep brain stimulation; fMR = functional magnetic resonance; GABA = $\gamma$-aminobutyric acid; FU = follow-up; NA = not available; $\mathrm{NS}=$ not stated $\mathrm{PAG}=$ periaqueductal gray area; $\mathrm{PW}=$ pulse width; $\mathrm{RCT}=$ randomized controlled trial; TGN = trigeminal neuralgia; TS = test stimulation.

$\dagger$ Results reported in conference proceedings. 
TABLE 1, continued

Summary of published data on the effects of MCS*

\begin{tabular}{|c|c|c|c|c|c|c|c|}
\hline \multirow{2}{*}{$\begin{array}{l}\text { Authors } \\
\& \mathrm{Yr}\end{array}$} & \multirow{2}{*}{$\begin{array}{l}\text { No. of } \\
\text { Cases }\end{array}$} & \multirow[b]{2}{*}{ Diagnosis } & \multicolumn{2}{|c|}{ Response } & \multirow{2}{*}{$\begin{array}{l}\text { Optimum } \\
\text { Settings }\end{array}$} & \multirow{2}{*}{$\begin{array}{l}\text { Adverse } \\
\text { Effects }\end{array}$} & \multirow[b]{2}{*}{ Comments } \\
\hline & & & Short Term & Long Term & & & \\
\hline $\begin{array}{l}\text { Katayama, } \\
\text { et al., } 1998\end{array}$ & 31 & poststroke pain & $\begin{array}{l}\text { initial testing for } \\
1 \mathrm{wk}: 23(74 \%) \\
\text { w/ good relief }\end{array}$ & $\begin{array}{l}15 \text { underwent device } \\
\text { implantation; good } \\
\text { pain reduction over } \\
\text { 2-yr FU; } 8 \text { had grad- } \\
\text { ual increase in pain } \\
\text { (no lead migration); } \\
\text { of } 18 \text { patients w/ } \\
\text { mild/no weakness in } \\
\text { area of pain, } 13 \text { had } \\
\text { good relief; of } 13 \text { w/ } \\
\text { moderate to severe } \\
\text { muscle weakness, } \\
\text { only } 2 \text { had good re- } \\
\text { lief; in } 20 \text { of } 31, \\
\text { muscle contraction } \\
\text { was inducible, } \& 14 \\
\text { of these had good } \\
\text { pain relief }\end{array}$ & $\begin{array}{l}\text { frequency } 20-25 \mathrm{~Hz} \text {, } \\
\text { intensity } 2-8 \mathrm{~V}\end{array}$ & NS & $\begin{array}{l}\text { preop evaluation } \\
\text { of motor strength } \\
\text { in painful area } \\
\text { appears useful for } \\
\text { predicting re- } \\
\text { sponse to MCS } \\
\text { for poststroke } \\
\text { pain }\end{array}$ \\
\hline \multirow[t]{2}{*}{$\begin{array}{l}\text { Nguyen, et } \\
\text { al., 1998† }\end{array}$} & 37 & $\begin{array}{l}\text { central \& peripheral neuro- } \\
\text { pathic pain }\end{array}$ & $\begin{array}{l}12 \text { of } 15 \mathrm{w} / \text { neuro- } \\
\text { pathic pain \& } 12 \\
\text { of } 14 \mathrm{w} / \text { central } \\
\text { pain; at least } 80 \% \\
\text { improvement }\end{array}$ & $\begin{array}{l}\text { all improved at } 4 \text { mos; } \\
5 \text { w/ positive re- } \\
\text { sponse in } 5 \text { selec- } \\
\text { ted for RCT }\end{array}$ & NS & NS & $\begin{array}{l}\text { good long-term re- } \\
\text { lief; positive re- } \\
\text { sponse in } 5 \text { of } 5 \\
\text { in RCT }\end{array}$ \\
\hline & 1 & $\begin{array}{l}\text { postop facial pain (removal } \\
\text { of acoustic neurinoma) }\end{array}$ & $\begin{array}{l}\text { complete relief of } \\
\text { pain (face) \& } \\
\text { tremor (arm) }\end{array}$ & $\begin{array}{l}\text { complete relief at } \\
32 \text { mos }\end{array}$ & $\begin{array}{l}\text { amp } 1.8 \mathrm{~V} \text {, cycling } \\
\text { mode: } 3 \text { hrs on, } \\
3 \text { hrs off, PW } 60 \\
\text { nsec, frequency } \\
50 \mathrm{~Hz} \text {; bipolar } \\
\text { stimulation (no. } \\
1 \text { electrode posi- } \\
\text { tive, no. } 2 \text { nega- } \\
\text { tive) }\end{array}$ & $\begin{array}{l}\text { no adverse } \\
\text { effect }\end{array}$ & $\begin{array}{l}\text { variation in pattern } \\
\text { of response dur- } \\
\text { ing different set- } \\
\text { tings of stimula- } \\
\text { tion; no evidence } \\
\text { of tolerance }\end{array}$ \\
\hline $\begin{array}{l}\text { Canavero, et } \\
\text { al., } 1999\end{array}$ & $\mathrm{t}$ & poststroke pain & $\begin{array}{l}\text { initial testing } \\
\text { showed lt arm- } \\
\text { ripping- \& } \\
\text { squeezing-in- } \\
\text { duced pain total- } \\
\text { ly gone; burning } \\
\text { pain reduced by } \\
50 \%\end{array}$ & $\begin{array}{l}\text { at } 5 \text { wks buring pain } \\
\text { returned; at } 6 \text { weeks } \\
\text { pain fully returned; } \\
\text { MCS switched off }\end{array}$ & $\begin{array}{l}\text { NS; high voltage } \\
\text { worsened the } \\
\text { pain }\end{array}$ & $\begin{array}{l}\text { at } 6 \text { wks } \\
\text { painful lt } \\
\text { supernum- } \\
\text { erary arm, } \\
\text { which oc- } \\
\text { curred once } \\
\text { every 1-2 } \\
\text { wks, \& } \\
\text { lasted 10- } \\
15 \text { mins }\end{array}$ & $\begin{array}{l}\text { reduced response } \\
\text { over } 5 \text { wks, pain } \\
\text { returned in } 6 \\
\text { wks; presence of } \\
\text { lt supernumerary } \\
\text { arm }\end{array}$ \\
\hline $\begin{array}{l}\text { Franzini, et } \\
\text { al., } 2000\end{array}$ & 1 & $\begin{array}{l}\text { thalamic hand } \\
\text { syndrome }\end{array}$ & complete recovery & up to 2 years & NS & $\mathrm{NS}$ & $\begin{array}{l}\text { full recovery in } \\
2 \mathrm{yr} \mathrm{FU}\end{array}$ \\
\hline $\begin{array}{l}\text { Nguyen, et } \\
\text { al., } 2000\end{array}$ & 32 & $\begin{array}{l}13 \mathrm{w} / \text { central pain;12 w/ } \\
\text { neuropathic facial pain; } \\
3 \mathrm{w} / \text { postparaplegic } \\
\text { pain; } 1 \mathrm{w} / \text { plexus avul- } \\
\text { sion; } 1 \mathrm{w} / \text { intercostal } \\
\text { herpes zoster }\end{array}$ & $\begin{array}{l}10(77 \%) \text { of } 13 \text { sub- } \\
\text { stantial relief; } 9 \\
(75 \%) \text { of } 12 \text { sub- } \\
\text { stantial relief; } 1 \text { of } \\
3 \text { clearly improved; } \\
2 \text { with satisfactory } \\
\text { improvement }\end{array}$ & $\begin{array}{l}\text { same relief w/ a mean } \\
\text { FU of } 27.3 \text { mos }\end{array}$ & NS & $\begin{array}{l}\text { none devel- } \\
\text { oped epilep- } \\
\text { tic seizures }\end{array}$ & $\begin{array}{l}22 \text { of } 30 \text { responded } \\
\text { to } \mathrm{MCS} \text { w/ a } \\
\text { mean FU of } 27.3 \\
\text { mos }\end{array}$ \\
\hline $\begin{array}{l}\text { Saitoh, et } \\
\text { al., } 2000\end{array}$ & 8 & $\begin{array}{l}4 \mathrm{w} / \text { thalamic pain; } 4 \mathrm{w} / \\
\text { peripheral deafferentation } \\
\text { pain }\end{array}$ & $\begin{array}{l}6 \text { w/ pain relief ( } 2 \\
\text { excellent, } 2 \text { good, } \\
2 \text { fair) }\end{array}$ & FU time NS & NS & NS & $\begin{array}{l}\text { no correlation } \\
\text { between pharma- } \\
\text { cological results } \\
\text { \& MCS }\end{array}$ \\
\hline $\begin{array}{l}\text { Roux, et } \\
\text { al., } 2001\end{array}$ & 1 & phantom-limb pain & $\begin{array}{l}70 \% \text { reduction } \\
\text { based on VAS } \\
\text { scores }\end{array}$ & FU time NS & NS & NS & $\begin{array}{l}\text { used fMR imaging } \\
\text { as an indicator } \\
\text { for electrode } \\
\text { placement }\end{array}$ \\
\hline
\end{tabular}

* amp = amplitude; DBS = deep brain stimulation; fMR = functional magnetic resonance; GABA = $\gamma$-aminobutyric acid; FU = follow-up; NA = not available; NS = not stated; PAG = periaqueductal gray area; $\mathrm{PW}=$ pulse width; $\mathrm{RCT}=$ randomized controlled trial; $\mathrm{TGN}=$ trigeminal neuralgia; $\mathrm{TS}=$ test stimulation.

$\dagger$ Results reported in conference proceedings. 
some patients. Effects attributed to surgery include epidural clots. ${ }^{13}$ Other effects directly attributed to MCS include epileptic and focal seizures, aphasia and dysphasia, upperextremity fatigue, burning sensations in the area of stimulation, and the presence of left-sided supernumerary arm in the affected area. ${ }^{3,13,15,18,19}$ No seizures or other complications have been reported as a result of long-term stimulation delivered at optimum settings.

\section{CLINICAL MATERIAL AND METHODS}

\section{Indications for MCS}

Given the reported outcomes of this procedure, patients in whom chronic neuropathic pain was refractory to conventional analgesic intervention were considered eligible for surgical implantation of an MCS device (Itrel II or III; Medtronic, Inc., Minneapolis, MN).

\section{Preoperative Investigations}

Predicting which patients will likely benefit from stimulation is a major clinical problem. Response does not appear to be condition specific. Barbiturate sensitivity and opioid insensitivity have been suggested as possible predictors of response. ${ }^{1,22,24}$ Transcranial magnetic stimulation may be another useful predictor of response. ${ }^{1,14}$ Another possible predictor in patients with poststroke pain could be the level of muscle strength demonstrated in the painful area. ${ }^{10}$ Results of such preoperative testing, however, are no guarantee of a successful outcome, as not all patients who respond to propofol respond to MCS and, equally, morphine-insensitive patients have been shown to respond to stimulation. ${ }^{1}$

We have not, therefore, routinely performed any specific investigations other than head computerized tomography and magnetic resonance imaging, preoperative chest radiography, electrocardiography and blood count, clotting screen, and serum chemistry.

\section{Surgical Technique}

At the Radcliffe Infirmary, the procedure is performed in two stages. After induction of general anesthesia the patient is positioned such that the side contralateral to pain lies uppermost, with a sandbag under the same shoulder to prevent venous congestion. The position of the central sulcus is marked using standard anatomical landmarks, but no other image guidance is used. The patient's hair is not shaved but is cleansed with chlorhexidine shampoo followed by alcoholic chlorhexidine. After draping the operative field, a horseshoe-shaped incision is marked $3 \mathrm{~cm}$ on either side of the central sulcus and extended to the midline for the leg and for faciobrachial pain the exposure ends $2 \mathrm{~cm}$ lateral to the midline. A free bone flap is raised, leaving the dura mater intact, following which the bone flap is tied down with three vicryl sutures, the wound closed in layers over a drain for 24 hours, and the patient awakened.

The following week the scalp and temporalis muscle are infiltrated with $0.25 \%$ bupivacaine after intravenous sedation. The scalp is prepared in the aforementioned manner with the patient's head in a horseshoe headrest and draped. The scalp is then reopened, retracted laterally, and the bone flap is removed. The patient is awake and cooperative at this time. We then use a four-lead Resume electrode (Medtronic, Inc.) with the extension lead running from the operative field to an external stimulator. The electrode is then moved over the dura parallel to the line of the central sulcus while applying stimuli to elicit motor contractions in the area of pain or, in cases of phantomlimb pain, until the patient reports sensations, usually of muscle contractions in the nonexistent limb. The stimulus parameters for exploration are 5 to $10 \mathrm{~Hz}$, and 3 to $5 \mathrm{~V}$ for demarcation of the motor strip. If the patient feels any discomfort from dura-related pressure, a lidocaine-soaked swab is placed over the dura to induce local anesthesia.

Once the best placement has been identified, the electrode is secured to the dura with silk sutures, the bone flap wired back in place, and most of the wound closed in two layers, except posteroventrally where the free end of the lead is placed under the skin and interrupted suture placed. This allows the drapes to be removed, induction of anesthesia, and redraping to incorporate the scalp neck and upper chest. The posterior part of the scalp wound is reopened, and the free electrode is connected to the extension lead, which is the tunneled to a subcutaneous subclavicular pocket to be connected to a pacemaker (Itrel III, Medtronic, Inc.). All wounds are then closed in two layers, and the patient is reawakened. Antibiotic agents are given for up to 3 days. No attempt to program the stimulator is made on this admission. All patients receive longterm anticonvulsant medication.

\section{Postoperative Care}

Within 6 weeks postoperatively the patients are routinely admitted to the Pain Relief Unit where they stay for a week to optimize the stimulation parameters to achieve the best possible reduction in pain. The specialist nurse performs all assessments of pain independently of the surgeon. The specialist nurse then conducts follow-up review of the patients on a regular basis, either by telephone or outpatient examination.

\section{RESULTS}

Details of the 12 patients are shown in Table 2. A motor response was elicted in all 12 patients during intraoperative stimulation, and implantation of the MCS device was performed in all 12. The effects of the procedure on pain relief were then independently assessed in the Pain Relief Unit. The protocol used included the following items: 1) pain intensity: a four-point verbal rating scale (severe pain, 3; moderate, 2; mild, 1 ; and no pain, 0 ) and a 10point numerical scale $(0-10) ; 2$ ) the McGill Pain Questionnaire; 3 ) pain relief: a five-point scale (no pain relief, 0; slight, 1; moderate, 2; good, 3; and complete pain relief, 4) and percentage of pain relief; 4) volunteered and observed adverse effects of treatment; 5) details of stimulator parameters (amplitude, pulse width, pulse rate, and electrode settings); and 6) use of other analgesic interventions.

Six of the 12 patients reported experiencing relief of pain during the first postoperative titration of the stimulator setting (Cases 1, 2, 4, 5, 8, and 12). In six patients stim- 
TABLE 2

Summary of data in 12 patients in whom an MCS device was implanted for refractory pain*

\begin{tabular}{|c|c|c|c|c|c|c|c|c|}
\hline $\begin{array}{l}\text { Case } \\
\text { No. }\end{array}$ & $\begin{array}{l}\text { Diagnosis/ } \\
\text { Yr of Onset }\end{array}$ & $\begin{array}{c}\text { Site of Pain/ } \\
\text { Characteristics }\end{array}$ & $\begin{array}{l}\text { Age (yrs), } \\
\text { Sex }\end{array}$ & $\begin{array}{c}\text { 1st Stage } \\
\text { of MCS } \\
\text { (2nd Stage) }\end{array}$ & $\begin{array}{l}\text { Adverse Effects/ } \\
\text { Complications }\end{array}$ & $\begin{array}{l}\text { Optimum } \\
\text { Settings }\end{array}$ & $\begin{array}{l}\text { Pain Relief/ } \\
\text { Duration }\end{array}$ & Comments \\
\hline 1 & $\begin{array}{l}\text { poststroke pain } \\
\text { (thalamic in- } \\
\text { farct), } 1991\end{array}$ & $\begin{array}{l}\text { hemibody; constant, } \\
\text { severe }\end{array}$ & $62, \mathrm{M}$ & $\begin{array}{l}11 / 95 \\
(11 / 95)\end{array}$ & $\begin{array}{l}\text { subdural hematoma, sec- } \\
\text { ondary wound infection; } \\
\text { explantation } 4 / 96\end{array}$ & $\begin{array}{l}\text { not doc- } \\
\text { umented }\end{array}$ & $\begin{array}{l}>50 \% \\
2-3 \text { wks }\end{array}$ & $\begin{array}{l}\text { initial pain relief } \\
(>50 \%) \text { lasted } 2-3 \\
\text { wks, died of unrelat- } \\
\text { ed cause } 6 / 96\end{array}$ \\
\hline 2 & $\begin{array}{l}\text { posttraumatic neu- } \\
\text { ralgia (brain- } \\
\text { stem gunshot } \\
\text { injury), } 1993\end{array}$ & $\begin{array}{l}\text { face, neck, arm, \& } \\
\text { shoulder; constant, } \\
\text { severe }\end{array}$ & $54, \mathrm{~F}$ & $\begin{array}{l}7 / 96 \\
(7 / 96)\end{array}$ & $\begin{array}{l}\text { tender over implant; sec- } \\
\text { ondary wound infection; } \\
\text { high amp stimulation } \\
\text { gave sense of tightness } \\
\text { in area of pain, impaired } \\
\text { speech }\end{array}$ & $\begin{array}{l}\operatorname{amp} 2.1 \mathrm{~V} \\
\text { PW } 450 \\
\mu \text { sec, } \\
\text { PR } 20 \mathrm{~Hz}\end{array}$ & $\begin{array}{r}50-60 \% \\
36 \text { mos }\end{array}$ & $\begin{array}{l}>50 \% \text { relief overall; } \\
\text { titration limited by } \\
\text { tightness \& other } \\
\text { symptoms }\end{array}$ \\
\hline 3 & $\begin{array}{l}\text { poststroke pain } \\
\text { (thalamic in- } \\
\text { farct), } 1985\end{array}$ & $\begin{array}{l}\text { facial; constant, } \\
\text { severe }\end{array}$ & $80, \mathrm{M}$ & $\begin{array}{l}3 / 96 \\
(3 / 98)\end{array}$ & & none found & none & $\begin{array}{l}\text { no relief; no clear } \\
\text { postop motor re- } \\
\text { sponse }\end{array}$ \\
\hline 4 & $\begin{array}{l}\text { poststroke (occi- } \\
\text { pital infarct), } \\
1990\end{array}$ & $\begin{array}{l}\text { hemibody; constant, } \\
\text { severe }\end{array}$ & $70, \mathrm{M}$ & $\begin{array}{l}7 / 96 \\
(12 / 96)\end{array}$ & $\begin{array}{l}\text { Itrel II affected by expo- } \\
\text { sure to external mag- } \\
\text { netic field }\end{array}$ & $\begin{array}{l}\text { amp } 5.0 \mathrm{~V} \\
\text { PW } 450 \\
\mu \mathrm{sec}, \\
\text { PR } 15 \mathrm{~Hz}\end{array}$ & $\begin{array}{l}100 \% \\
31 \mathrm{mos}\end{array}$ & $\begin{array}{l}\text { no pain since } 10 / 98 \text {; } \\
\text { stimulator switched } \\
\text { off } 2 / 99 \text { w/ no recur- } \\
\text { rence of pain; died } \\
\text { of unrelated cause } \\
7 / 99\end{array}$ \\
\hline 5 & $\begin{array}{l}\text { phantom \& stump } \\
\text { pain, } 1992\end{array}$ & leg; constant, severe & $48, \mathrm{M}$ & $\begin{array}{l}1 / 97 \\
(1 / 97)\end{array}$ & $\begin{array}{l}\text { higher amp yielded tight- } \\
\text { ness in area of pain }\end{array}$ & $\begin{array}{l}\text { amp } 7.0 \mathrm{~V} \\
\text { PW } 450 \\
\mu \text { sec, } \\
\text { PR } 25 \mathrm{~Hz}\end{array}$ & $\begin{array}{l}70 \% \text { phan- } \\
\text { tom } 0 \% \\
\text { stump, } 30 \\
\text { mos }\end{array}$ & $\begin{array}{l}\text { good relief phantom } \\
\text { pain; no relief of } \\
\text { stump pain }\end{array}$ \\
\hline 6 & $\begin{array}{l}\text { neurofibromato- } \\
\text { sis, } 1990\end{array}$ & arm; constant, severe & $55, \mathrm{~F}$ & $\begin{array}{l}1 / 97 \\
(1 / 97)\end{array}$ & no postop motor response & none found & none & $\begin{array}{l}\text { no pain relief; no } \\
\text { postop motor re- } \\
\text { sponse; MCS dis- } \\
\text { continued }\end{array}$ \\
\hline 7 & $\begin{array}{l}\text { poststroke pain } \\
\text { (thalamic in- } \\
\text { farct), } 1990\end{array}$ & $\begin{array}{l}\text { hemibody; constant, } \\
\text { severe }\end{array}$ & $63, \mathrm{~F}$ & $\begin{array}{l}3 / 97 \\
(3 / 97)\end{array}$ & & none found & none & $\begin{array}{l}\text { no clear reproducible } \\
\text { postop motor re- } \\
\text { sponse; no pain re- } \\
\text { lief; MCS discon- } \\
\text { tinued }\end{array}$ \\
\hline 8 & $\begin{array}{l}\text { phantom limb } \\
\text { pain, } 1975\end{array}$ & $\begin{array}{l}\text { arm \& hand; constant, } \\
\text { severe }\end{array}$ & $56, \mathrm{~F}$ & $\begin{array}{l}4 / 97 \\
(4 / 97)\end{array}$ & $\begin{array}{l}\text { secondary wound infection; } \\
\text { pain over implant site }\end{array}$ & $\begin{array}{l}\operatorname{amp} 2.5 \mathrm{~V} \\
\mathrm{PW} 450 \\
\mu \mathrm{sec}, \mathrm{PR} \\
75 \mathrm{~Hz}\end{array}$ & $\begin{array}{l}\operatorname{arm} 75 \%, \\
\text { hand } 5 \%, \\
27 \operatorname{mos}\end{array}$ & $\begin{array}{l}\text { good long-term relief } \\
\text { of phantom pain }\end{array}$ \\
\hline 9 & $\begin{array}{l}\text { phantom limb } \\
\text { pain, } 1979\end{array}$ & arm; constant severe & $39, \mathrm{M}$ & $\begin{array}{l}10 / 97 \\
(10 / 97)\end{array}$ & $\begin{array}{l}\text { no postop motor response; } \\
\text { possible contact w/ ex- } \\
\text { ternal magnetic field }\end{array}$ & none found & none & $\begin{array}{l}\text { technical failure; } \\
\text { MCS discontinued }\end{array}$ \\
\hline 10 & $\begin{array}{l}\text { poststroke pain } \\
\text { (brainstem) \& } \\
\text { TGN, } 1992\end{array}$ & $\begin{array}{l}\text { facial burning; con- } \\
\text { stant, severe, epi- } \\
\text { sodic }\end{array}$ & $80, \mathrm{~F}$ & $\begin{array}{l}2 / 98 \\
(3 / 98)\end{array}$ & $\begin{array}{l}\text { fit induced during postop } \\
\text { titration }(9.6 \mathrm{~V}) \text {; no pain } \\
\text { relief despite motor re- } \\
\text { sponse during postop } \\
\text { titration }\end{array}$ & none found & none & $\begin{array}{l}\text { clear reproducible } \\
\text { postop motor re- } \\
\text { sponse }(8 \mathrm{~V}) \text {; no } \\
\text { pain relief; MCS } \\
\text { discontinued }\end{array}$ \\
\hline 11 & $\begin{array}{l}\text { brachial plexus } \\
\text { avulsion, } 1976\end{array}$ & $\begin{array}{l}\text { hand \& arm; con- } \\
\text { stant, variable in- } \\
\text { tensity }\end{array}$ & $36, \mathrm{~F}$ & $\begin{array}{l}11 / 99 \\
(1 / 99)\end{array}$ & $\begin{array}{l}\text { strong motor response } \\
\text { during intraop TS; } \\
\text { during intraop TS \& } \\
\text { postop titration }\end{array}$ & none found & none & $\begin{array}{l}\text { evidence of motor re- } \\
\text { sponse postop, no } \\
\text { pain relief; MCS } \\
\text { discontinued }\end{array}$ \\
\hline 12 & $\begin{array}{l}\text { poststroke pain, } \\
1997\end{array}$ & $\begin{array}{l}\text { hemibody; constant, } \\
\text { moderate-to-severe }\end{array}$ & $68, \mathrm{M}$ & $\begin{array}{l}3 / 99 \\
(3 / 99)\end{array}$ & $\begin{array}{l}\text { strong motor response } \\
\text { during intraop TS }\end{array}$ & $\begin{array}{l}\text { awaiting } \\
\text { retitration }\end{array}$ & $\begin{array}{l}2 \text { wks re- } \\
\text { lief from } \\
\text { initial post- } \\
\text { op titration; } \\
\text { awaiting } \\
\text { further ti- } \\
\text { tration }\end{array}$ & $\begin{array}{l}\text { complete relief of } \\
\text { pain from propofol; } \\
\text { initial postop titra- } \\
\text {; tion produced } 70 \% \\
\text { relief of pain in arm } \\
\& \text { hand for } 2-3 \mathrm{wks}\end{array}$ \\
\hline
\end{tabular}

$* \mathrm{PR}=$ pulse rate.

ulation failed to achieve any pain relief despite extensive attempts during titration (Cases 3, 6, 7, and 9-11).

\section{Patients With Pain Relief}

Of the six patients who reported pain relief during MCS, three suffered from central poststroke pain (Cases
1,4 , and 12), one posttraumatic neuralgia (Case 2), and two from phantom-limb pain (Case 5 [lower limb] and Case 8 [upper limb]), of 2 to 13 years' duration. There was a clear reproducible motor response (muscle spasm, tightness, or tingling sensation) evoked in the area of pain during both intra- and postoperative titration in all six patients 
who reported pain relief. Pain relief varied from 50 to $90 \%$ (compared with baseline pain). No patient reported complete relief of pain for any significant period of time during titration. Long-term pain relief (most recent assessment ranged between 21 months and 50 months postimplantation) was maintained in all except two patients (Cases 1 and 12). The patient in Case 1 was in poor general health before MCS surgery and reported a reduction in pain after 2 to 3 weeks of stimulation. This was associated with a low impedance, and surgical exploration confirmed that the insulation of the electrode cable was damaged and this was replaced. Postreplacement, it was not possible to replicate the same level of pain relief previously attained ( $>50 \%$ relief). Unfortunately this patient developed a secondary wound infection and the device had to be removed. Postoperatively a subdural hematoma formed, which required further surgery. The patient later died of a pulmonary embolism.

Hardware-related problems were demonstrated in five patients who responded to MCS. Such problems always presented as a sudden and unanticipated increase in pain. The patient in Case 4 suffered three episodes in which the pain returned to its original intensity. On each occasion the device had unexplainably switched off. We believe that the patient had been exposed to a magnetic field (ultrasonography on one occasion) which interfered with the device. In two patients (Cases 5 and 8) damaged leads needed to be replaced. In Case 5 this was because the patient sustained trauma while rapidly elevating his arms above his head. In Case 8 there was no clear explanation for the damage. Unfortunately in this same patient a previously faulty pulse generator (Itrel II), had been replaced with a different model (Itrel III). Interestingly, as with the patient in Case 1, in Case 8 titration after the second and third operations was far from straightforward. Although excellent pain relief was eventually achieved, this required several inpatient sessions. In the patient in Case 2, the titration process was not straightforward because of preexisting neurological symptoms related to the original severe brainstem injury that were exacerbated whenever the stimulation was increased. She could not tolerate stimulation above $2.5 \mathrm{~V}$ because of dysarthria and increased tightness over the site of her pain, even though increased pain relief was achieved at higher levels. Similar stimulation-related problems were encountered in the patient in Case 5 , in whom a $7-\mathrm{V}$ stimulation induced a $90 \%$ reduction of phantom-arm pain. Increasing the intensity of during titration produced $100 \%$ relief of pain, but the patient could not tolerate the feeling of tightness and tiredness, which appeared to replace the phantom pain. Titration was hindered by the presence of multiple pain sites in four (Cases 2, 4, 5, and 8) of the six patients in whom a positive response to MCS was found. Although the patient in Case 5 experienced good relief of most of the pain in the phantom limb, it was not possible to relieve the burning pain in his toes, nor the local stump pain, which was aggravated by an ill-fitting prosthesis; overall he reported a $70 \%$ improvement in his pain. Similarly, although the patient in Case 8 experienced good relief of pain in the phantom arm, which was the site of her worst pain before MCS implantation, it was not possible to produce any significant pain relief in her hand without diminishing the pain relief in her arm.
No patient who reported MCS-induced pain relief experienced epileptic or focal seizures at any time. The patients in Cases 2 and 8 complained of local tenderness and hypersensitivity over the electrode site, which neither resolved nor diminished over time. The patient in the latter case developed a secondary wound infection after the operation to repair the electrodes, which was successfully treated with antibiotic therapy. The patient in the former case developed a scalp infection that required surgical debridement.

\section{Patients Without Pain Relief}

Six patients failed to respond to MCS despite extensive attempts to determine optimum stimulation parameters during postoperative titration. Details are given in Table 2. No clear postoperative motor response was ever elicited in four of these patients (Cases 3, 6, 7, and 9). In these four patients no clinically observable signs of active stimulation were demonstrated after implantation of the system. We failed to elicit any motor response postoperatively in Case 7. Case 9 was considered to be a clear technical failure as the patient succeeded in wiping the identification number from his internally implanted programming device when repairing large high-fidelity speakers. He inflicted deliberate damage to the stimulator leads by repeatedly rotating the pulse generator under his skin. In the patients in Cases 10 and 11, a clear and reproducible motor response was elicited. The former patient exhibited muscle spasm in the right side of her face directly in the area of pain, together with expressive dysphasia. There was a clear dose response for these motor signs. Even very small increases in the stimulation $(0.5 \mathrm{~V})$ were sufficient to change the initial expressive dysphasia into a focal arrest, together with a marked increase in muscle spasm. This patient did not experience any change in her pain status, even with prolonged periods of continous stimulation at amplitudes up to $5 \mathrm{~V}$. Stimulation at higher levels resulted in a full epileptic seizure, and the device was eventually switched off. Such extreme effects were not seen in any other patients, even at high levels of stimulation (for example, $10 \mathrm{~V}$ in Case 9). The patient in Case 11 exhibited muscle tightness and spasm in her arm; she, too, also experienced seizures, both intra- and postoperatively.

\section{Randomised, Double-blinded, Within-Patient Cross-Over Trial}

Patients reporting at least 50\% long-term ( $>6$ months) intermittent MCS-induced pain relief were invited to take part in this randomized, double-blind, within-patient repeated cross-over study, which was approved by the local hospital ethics committee.

\section{Study Procedure}

For practical reasons, patients were admitted to hospital for the duration of the study.

Eligible patients were allocated to receive up to $10 \mathrm{se}$ quential treatment periods of both: 1) active stimulation (five treatments); and 2) no stimulation (five treatments).

Study treatments were given in a random order (tossing of coin), and the randomization schedule was concealed (sealed envelopes for each treatment, identified by patient 
name and treatment number [1-10]). The treatments were double blinded. The person operating the IPG (on/off stimulation switch) was not involved with study assessments and had no other contact with patients. The nurse observer was unaware of the randomization schedule, and active stimulation was at subthreshold levels for any motor response.

Each treatment was given for a minimum of 1 hour and until the patients were able to make a prospective judgment as to whether the stimulator was currently on or off during each treatment (because of subjective changes in pain).

Pain intensity and pain relief were assessed immediately before each study treatment and then immediately before patients requested that they be switched over to the next treatment, according to the randomization schedule.

Pain was assessed using the following measures: 1) four-point verbal rating scale for pain intensity (severe pain, 3; moderate, 2; mild, 1; and no pain, 0); 2) five-point verbal rating scale for pain relief (no pain, 0; slight, 1; moderate, 2; good, 3; and complete pain relief, 4); 3) a 10$\mathrm{cm}$ VAS for pain intensity (from least possible pain [0] to worst possible pain [10]); and 4) a 10-cm VAS for pain relief (from no relief of pain [0] to complete relief of pain [10]).

Patients were also asked to make an overall rating of each treatment (poor, 0; fair, 1; good, 2; very good, 3; and excellent, 4) before receiving the next study treatment.

\section{Results of the Trial}

Three of the six patients with long-term MCS-induced pain relief were willing and able to take part in the study (Table 2). Two of these patients died of unrelated causes before the study was set up.

Of the three patients who took part, two were able to judge correctly when they received the active- and nostimulation treatments on eight of 10 occasions because of clinically relevant changes (decrease/increase) in their pain. Each cross-over treatment lasted for 1 hour, and treatments were given across 2 consecutive days.

One patient only guessed correctly which treatment she had received on four of 10 occasions. She reported that the study treatment periods ( 1 to 2 hours) were not long enough for her to have made a reliable judgment.

\section{Conclusions of the Trial}

In our experience, $50 \%$ of patients treated so far have responded positively to MCS ( $>50 \%$ pain relief). A positive response was achieved in phantom pain (two cases), poststroke pain (three cases), and posttraumatic neuralgia (one case). We found that it is impossible to predict which patients are likely to respond to MCS prior to treatment, as response does not appear to be condition specific. Once pain relief is achieved patients may need further retitration and fine tuning of the stimulator setting. The findings of the randomized double-blind trial suggest that patients are able to distinguish between active- and no-stimulation treatments because of a clinically relevant change in pain.

\section{DISCUSSION}

Multiple surgical procedures have been attempted over the years to manage the intractable nature of neuropathic pain. Surgery in which lesions are created is fraught with hazardous side effects that can be as bad or worse than the original complaint and should be avoided. Hence, neuromodulatory techniques have been explored. Over the last decade the authors of several series have reported on in the efficacy of MCS. As Table 1 shows there is still no obvious clear-cut indication for the procedure except that it would appear most effective in cases of facial and phantom pain syndromes. Poststroke pain in the presence of severe motor deficits, however, should be considered a contraindication.

Hardware-related failure (lead fractures, migration, and insulation fractures) is another important issue. Because the leads are placed extradurally, as the skull heals over any problems that occur, revision procedures are much more difficult. In very few papers have the authors addressed this issue, but in our experience hardware-related problems were encountered in five of those patients in whom MCS-induced responses occurred: two lead fractures; two pacemakers (Itrel IIs) stopped working and were replaced; and one pacemaker switched on and off the times unpredictably in one patient. Consequently there were four additional operative procedures. These complications are in agreement with the those reported by authors implanting neurostimulators for movement disorders in which hardware-related problems occured in 8 to $65 \%$ of patients (with associated morbidity and additional costs of treatment).

Our experience and a review of the literature suggest that MCS is an effective therapy for neuropathic pain in approximately $50 \%$ of cases in the long term. Very little is published regarding potential technical problems associated with this technique, but hopefully as larger series accrue with longer follow-up periods these questions may be addressed.

\section{References}

1. Canavero S, Bonicalzi V: Cortical stimulation for central pain. J Neurosurg 83:1117, 1995

2. Canavero S, Bonicalzi V, Castellano G, et al: Painful supernumerary phantom arm following motor cortex stimulation for central poststroke pain. Case report. J Neurosurg 91:121-123, 1999

3. Ebel H, Rust D, Tronnier V, et al: Chronic precentral stimulation in trigeminal neuropathic pain. Acta Neurochir 138: 1300-1306, 1996

4. Editorial: Electrical stimulation of the brain. Lancet 2:562, 1974

5. Franzini A, Ferroli P, Servello D, et al: Reversal of thalamic hand syndrome by long-term motor cortex stimulation. J Neurosurg 93:873-875, 2000

6. Fujii M, Ohmoto Y, Kitahara T, et al: [Motor cortex stimulation therapy in patients with thalamic pain.] No Shinkei Geka 25: 315-319, 1997 (Jpn)

7. Garcia-Larrea L, Peyron R, Mertens P, et al: Positron emission tomography during motor cortex stimulation for pain control. Stereotact Funct Neurosurg 68:141-148, 1997

8. Herregodts P, Stadnik T, De Ridder F, et al: Cortical stimulation for central neuropathic pain: 3-D surface MRI for easy determination of the motor cortex. Acta Neurochir Suppl 64: 132-135, 1995

9. Hosobuchi Y: Motor cortical stimulation for control of central deafferentation pain. Adv Neurol 63:215-217, 1993 
10. Katayama Y, Fukaya C, Yamamoto T: Poststroke pain control by chronic motor cortex stimulation: neurological characteristics predicting a favorable response. J Neurosurg 89:585-591, 1998

11. Katayama Y, Tsubokawa T, Yamamoto T, et al: Characterization and modification of brain activity with deep brain stimulation in patients in a persistent vegetative state: pain-related late positive component of cerebral evoked potential. Pacing Clin Electrophysiol 14:116-121, 1991

12. Katayama Y, Tsubokawa T, Yamamoto T: Chronic motor cortex stimulation for central deafferentation pain: experience with bulbar pain secondary to Wallenberg syndrome. Stereotact Funct Neurosurg 62:295-299, 1994

13. Meyerson BA, Lindblom U, Linderoth B, et al: Motor cortex stimulation as treatment of trigeminal neuropathic pain. Acta Neurochir Suppl 58:150-153, 1993

14. Migita K, Uozumi T, Arita K, et al: Transcranial magnetic coil stimulation of motor cortex in patients with central pain. Neurosurgery 36:1037-1040, 1995

15. Nguyen JP, Keravel Y, Feve A, et al: Treatment of deafferentation pain by chronic stimulation of the motor cortex: report of a series of 20 cases. Acta Neurochir Suppl 68:54-60, 1997

16. Nguyen JP, Lefaucheur JP, Le Guerinel C, et al: Motor cortex stimulation in the treatment of central and neuropathic pain. Arch Med Res 31:263-265, 2000

17. Nguyen JP, Pollin B, Feve A, et al: Improvement of action tremor by chronic cortical stimulation. Mov Disord 13:84-88, 1998

18. Peyron R, Garcia-Larrea L, Deiber MP, et al: Electrical stimulation of precentral cortical area in the treatment of central pain: electrophysiological and PET study. Pain 62:275-286, 1995
19. Rainov NG, Fels C, Heidecke V, et al: Epidural electrical stimulation of the motor cortex in patients with facial neuralgia. Clin Neurol Neurosurg 99:205-209, 1997

20. Roux FE, Ibarrola D, Lazorthes Y, et al: Chronic motor cortex stimulation for phantom limb pain: a functional magnetic resonance imaging study: technical case report. Neurosurgery 48: 681-688, 2001

21. Saitoh Y, Shibata M, Hirano S, et al: Motor cortex stimulation for central and peripheral deafferentation pain. Report of eight cases. J Neurosurg 92:150-155, 2000

22. Tsubokawa T, Katayama Y, Yamamoto T, et al: Chronic motor cortex stimulation in patients with thalamic pain. J Neurosurg 78:393-401, 1993

23. Tsubokawa T, Katayama Y, Yamamoto T, et al: Chronic motor cortex stimulation for the treatment of central pain. Acta Neurochir Suppl 52:137-139, 1991

24. Yamamoto T, Katayama Y, Hirayama T, et al: Pharmacological classification of central post-stroke pain: comparison with the results of chronic motor cortex stimulation therapy. Pain 72: $5-12,1997$

Manuscript received July 19, 2001.

Accepted in final form August 9, 2001.

Dr. T.Z. Aziz is supported by the Medical Research Council, United Kingdom and Dr. Nandi by the Norman Collisson Foundation.

Address reprint requests to: T. Z. Aziz, F.R.C.S., Department of Neurosurgery, Radcliffe Infirmary, Woodstock Road, Oxford OX2 6HE, United Kingdom. email: tipuaziz@ btinternet.com. 